\title{
Magnetic signature of submarine volcanoes in the Phlegrean Fields-Ischia Ridge (North-Western side of the Bay of Naples, Southern Italy)
}

\author{
Valeria Paoletti $\left({ }^{1}\right)$, Antonio Rapolla $\left({ }^{1}\right)\left({ }^{2}\right)$ and Manuela Secomandi \\ $\left.{ }^{1}{ }^{1}\right)$ C.U.G.RI., Consorzio inter-Universitario per la Previsione e Prevenzione dei Grandi Rischi \\ and clo Dipartimento di Scienze della Terra, Laboratorio di geofisica, Napoli, Italy \\ $\left.{ }^{2}{ }^{2}\right)$ Dipartimento di Scienze della Terra, Università degli Studi «Federico II», Napoli, Italy
}

\begin{abstract}
This paper presents a study of the Phlegrean Fields-Ischia submarine ridge by the analysis and interpretation of high-resolution aeromagnetic data recently acquired in the Western Procida offshore. The investigated area is located along the ridge connecting Ischia to the Phlegrean Fields and is characterized by the existence of several monogenetic volcanoes aligned on a NE-SW system of faults. The high-resolution magnetic data yielded new information on the area, highlighting particularly the signature of a volcanic body located between Pt. Serra and the Ruommoli shoal. This structure has not been clearly described before and we named it as the Pt. Serra submarine volcano. The computation of the analytic signal and horizontal gradient of the data distinctly located this structure and definined the position of its rims. A 2D modeling and 3D inversion of data provided information on the volcano's thickness, width and magnetization, disclosing a meaningful igneous body extending down to several hundred meters b.s.l.
\end{abstract}

Key words Aeromagnetic survey - Submarine volcanoes - Phlegrean Fields-Ischia Ridge - Procida offshore

\section{Introduction}

The Phlegrean Fields, along with the islands of Ischia and Procida, are active volcanoes developed on a ENE-WSW structural trend bordering the North-Western side of the Bay of

Mailing address: Dr. Valeria Paoletti, CUGRI, Viale Kennedy 5, 80125 Naples and c/o Dipartimento di Scienze della Terra, Laboratorio di Geofisica, Complesso Universitario di Monte Sant'Angelo, Via Cintia, Edificio 7, 80126 Napoli, Italy: fax: 39081679293 ; e-mail: paoletti@unina.it
Naples, Southern Italy (fig. 1). The volcanic activity in this area, which started in Upper Pleistocene, is controlled by regional strain fields (Di Girolamo et al., 1984; Vezzoli, 1988). Ischia and Procida are the emerged part of a main volcanic ridge separating a continental shelf to the North-West from a deeper sea floor topography to the South-East, in correspondence with the Bay of Naples (De Alteris and Toscano, 2003). The Ischia and Procida offshore areas are characterized by several monogenetic edifices aligned along a NE-SW system of faults that connects the South-Eastern sector of Ischia to the Phlegrean Fields (Di Girolamo and Stanzione, 1973). The existence of this group of faults was confirmed by gravity data (Imbò et al., 1964). The monogenic edifices of the area have been mainly formed through subaqueous explosive eruptions (hyaloclastites) of 


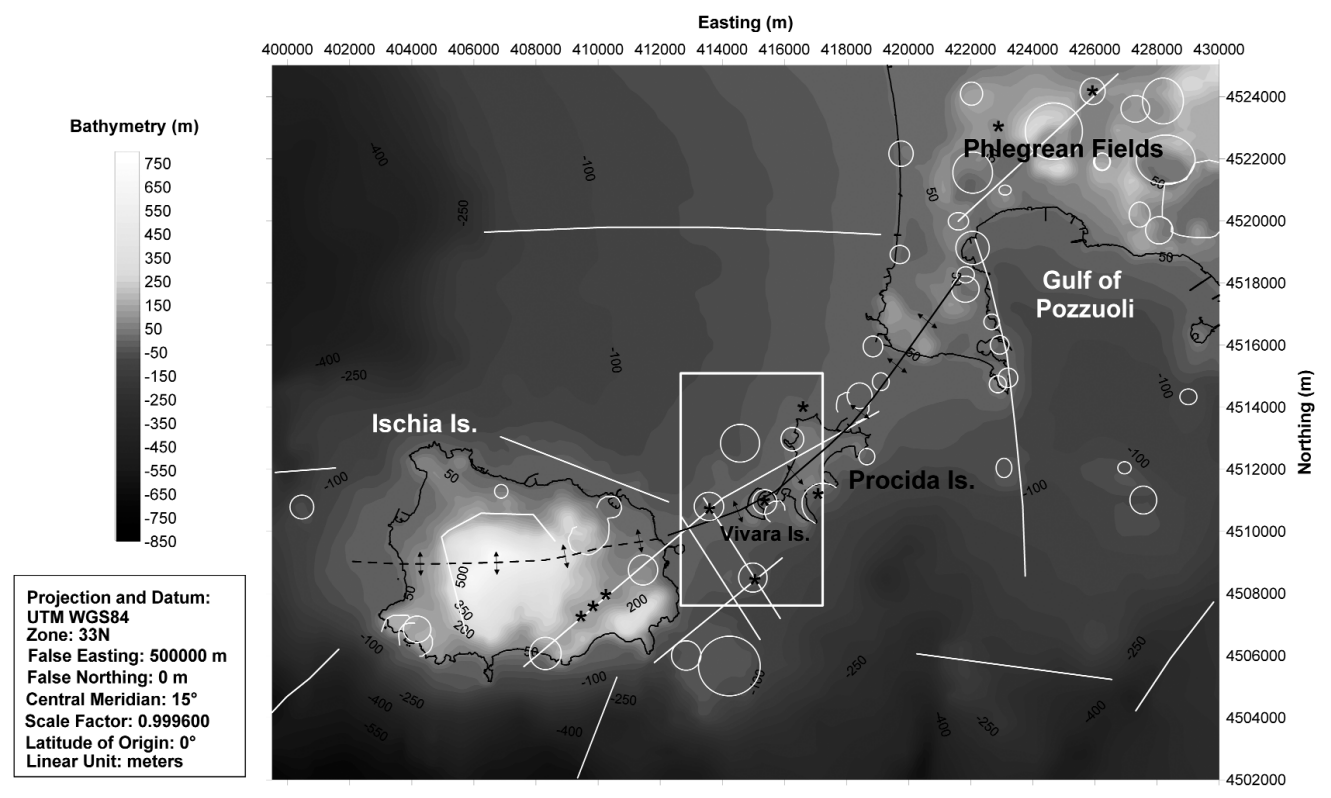

Fig. 1. Topographic and bathymetric map of the Phlegrean Fields-Ischia ridge. The main structural features are redrawn from Di Girolamo and Rolandi (1975): white lines are faults, black lines are ridges, circles are crater rims, asterisks are latitebasaltic and latite volcanoes. The square shows the area considered in this study.

a potassic magma with latitebasaltic-latitic composition (Di Girolamo and Rolandi, 1975); a few lava domes can also be found (Di Girolamo et al., 1984). Petrochemical correlations with the volcanics from the nearby islands of Procida, Vivara and Ischia show a close similarity for all the magmatic products of this region (Di Girolamo and Rolandi, 1975).

In this study we aim to gain insight into the features of the Phlegrean Fields-Ischia submarine ridge from the analysis and interpretation of high-resolution aeromagnetic data recently acquired in the Western Procida offshore (fig. 2 ). It is well-known that magnetic anomaly maps can provide useful information about the geo-volcanologic and structural characteristics of submarine volcanic areas.

Despite the geo-structural complexity characterizing the onshore and offshore areas of the Phlegrean Fields and Ischia, little information on this region derived from high-resolution magnetic data are presently available. The first detailed magnetic map of the Gulf of Naples, shown in Siniscalchi et al. (2002), was based on data collected during a high-resolution oceanographic cruise. Later Secomandi et al. (2003) performed a boundary analysis on these data showing the pattern of the magnetic sources and structures of the gulf. Aiello et al. (2005) combined the interpretation of the magnetic and seismic data measured during the above cited cruise and described the buried volcanic structures of the Gulf of Naples.

High resolution aeromagnetic surveys performed recently in the Phlegrean Fields (Paoletti et al., 2004) and Vesuvian regions (Paoletti et al., 2005a) allowed the characterization of some of the main geo-structural features of these areas. The integration of different highresolution magnetic data sets measured in the Neapolitan district yielded an overall view of the magnetic structures of the whole volcanic region (Paoletti et al., 2005b).

As regards the Ischia Island surroundings, Bruno et al. (2002) and de Alteris et al. (2002) analysed $600 \mathrm{~km}$ of new seaborne seismic and magnetic profiles in the Western offshore of the island. The study allowed the authors to high- 


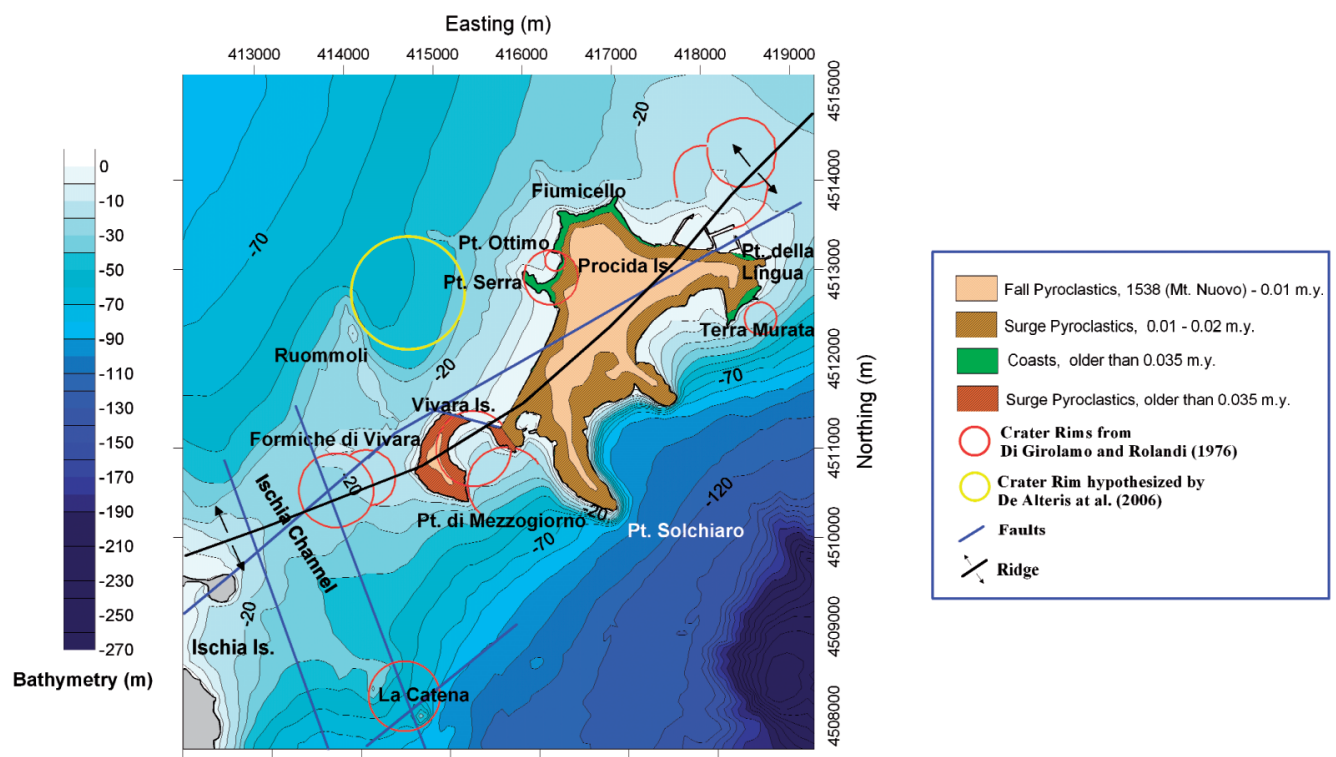

Fig. 2. Geologic map of the Procida Island and bathymetric map of its Western offshore. The geological units are from Di Girolamo et al. (1984). The main lineaments are redrawn from Di Girolamo and Rolandi (1975). The crater rims are from Di Girolamo and Rolandi (1975) and De Alteris et al. (2006). Bathymetry digitized from De Alteris et al. (2006).

light previously unreported E-W and NE-SW volcanic ridges that follow the regional structural patterns.

However these studies did not directly involve the Island of Ischia and the Phlegrean Fields-Ischia Ridge. Therefore, given the lack of detailed magnetic data on this region, a new high-resolution airborne survey was carried out in 2005. The survey covered the island of Ischia and the nearby submarine areas (fig. 3a). This paper focuses on the data measured in the western offshore of Procida Island (fig. 3b) and we aim at the characterization of the main submarine volcanic structures of this zone.

\section{Survey Layout and Data Processing}

\subsection{Logistical characteristics of the survey}

The helicopter-borne survey covered the entire area of the island of Ischia, extending also to the near Western Procida offshore (fig. 3). The investigation was set up in the form of a conventional airborne survey with a line spacing of $300 \mathrm{~m}(\mathrm{~N}-\mathrm{S}$ azimuth) and tie-lines (E-W azimuth) $4 \mathrm{~km}$ apart. The sample spacing along each flight line was about $5 \mathrm{~m}$. The survey was flown at a constant clearance of about $300 \mathrm{~m}$. To avoid some numerical problems during the successive gridding phases that could be related to the different sample rate in the N-S and E-W directions, we re-sampled the data along each line with a spacing of $50 \mathrm{~m}$.

The instrumentation used for the survey was supplied by the Geological Survey of Austria and included ground and flight units. The ground unit consists of a magnetometer used to monitor the external field activity during the flights and a GPS base receiver used for the differential correction of satellite data. The flight unit includes: 1) a cesium magnetometer measuring the total magnetic field intensity with a sensitivity of $0.01 \mathrm{nT}$. The magnetometer sensor was mounted in a «bird» towed $30 \mathrm{~m}$ beneath the helicopter; 2) a GPS receiver for the horizontal positioning of the helicopter, having an accuracy of about $\pm 1 \mathrm{~m}$ after post- 


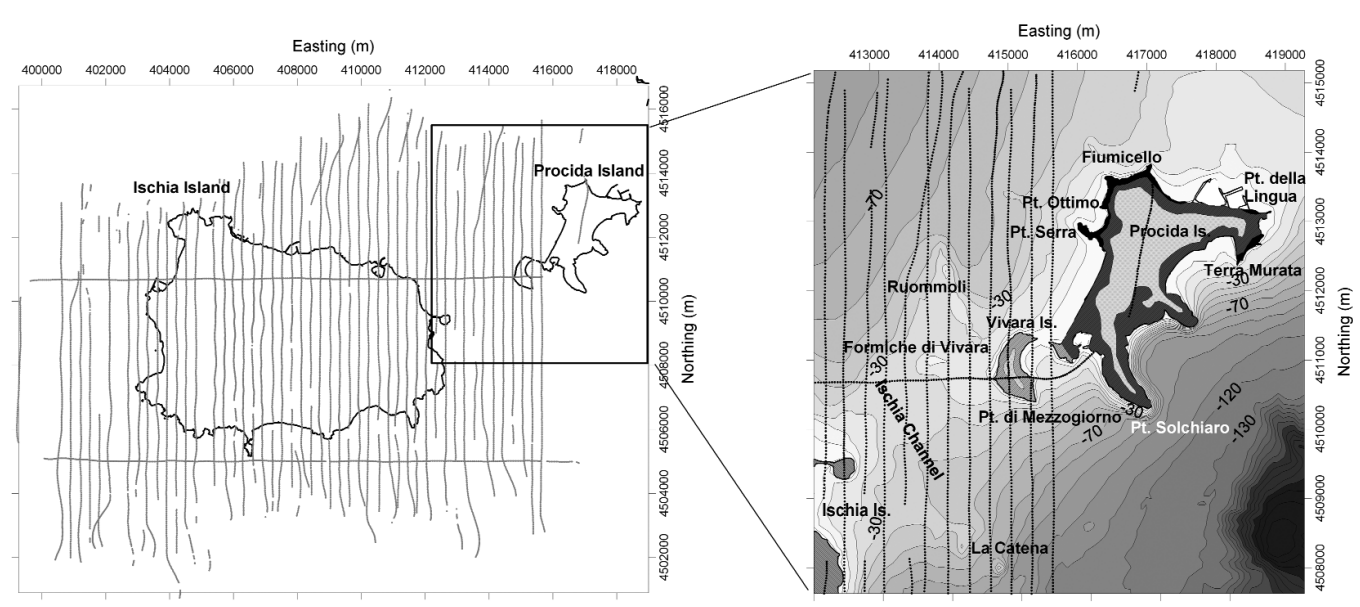

B)

Fig. 3a,b.A) Network of aeromagnetic profiles collected over Ischia Island in October 2005 (from Paoletti et al. 2009); B) Close-up of the lines flown in the Western Procida Island offshore.

processing of GPS data, 3) a laser-altimeter for the vertical positioning of the helicopter, 4) computer for data acquisition and 5) a videocamera.

\subsection{Data processing}

The processing of the aeromagnetic data set acquired over the island of Ischia, from which we took the data set analyzed in this paper, included the following steps: 1) removal of spikes and gaps in the aeromagnetic data;2) flight path check and repositioning, differential correction of the GPS data and check of the flight altitude; 3) Earth's magnetic field diurnal variation correction, performed using the base station data; 4) removal of the International Geomagnetic Reference Field (IGRF), performed using the Italian Geomagnetic Reference Field updated for 2000 (De Santis et al., 2003); 5) statistical leveling and crossover analysis, consisting in a minimization of differences between magnetic field values measured at crossing points of flight lines and tie-lines.

\section{Aeromagnetic Data of the Western Proci- da Offshore}

As we can see in fig $3 \mathrm{~b}$, the surveyed area covered the known shoals of Ruommoli, Formiche di Vivara and La Catena. Di Girolamo and Rolandi (1975) thoroughly studied the structures of Formiche di Vivara and La Catena and identified them as remnants of submarine latitebasaltic-latitic pyroclastic volcanoes formed through subaqueous explosive eruptions. The cited authors, and later Ferranti et al. (1994), found that the hyaloclastites volcano of Formiche di Vivara is the relict of a tuff ring with a terminal lava dome of the same latitebasaltic-latitic composition. This lava bank is $400 \mathrm{~m}$ long and $200 \mathrm{~m}$ wide and has a thickness of at least $7 \mathrm{~m}$. For their tectonic position and petrochemical characteristics, the Formiche di Vivara and La Catena edifices are considered as a junction between the islands of Ischia and Procida-Vivara (Di Girolamo and Rolandi, 1975). An exploration of the sea floor in the Ischia Channel allowed De Alteris et al. (1997) to interpret the shoal of Ruommoli as the relict of a mostly subaerial morphogenesis 


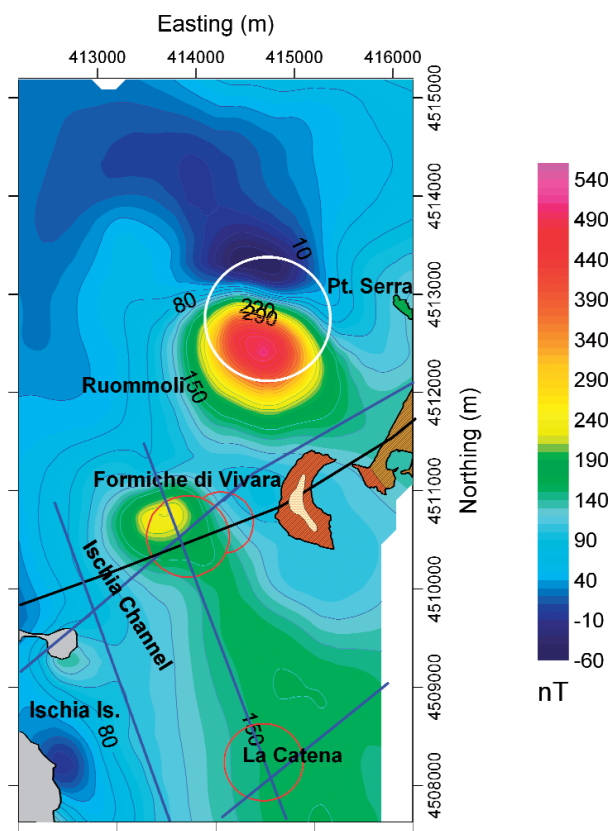

Fig. 4. High resolution aeromagnetic field of the Western Procida offshore. The rim of the tuff structure hypothesized by De Alteris et al. (2006) is drawn as a white circle, red circles show the rims of the Formiche di Vivara and La Catena volcanoes. The black line is the NE-SW ridge connecting Ischia and Phlegrean Fields. Faults are outlined by blue lines. For the geological units of the Procida Island refer to the legend of fig. 2 .

on a monogenic edifice composed of hyaloclastic tuff. The original shape of this edifice is no longer traceable.

Figure 4 shows the aeromagnetic map of the Western Procida offshore obtained by gridding the data at a $150 \mathrm{~m}$ cell size with a kriging algorithm. The main feature of the map is a prominent anomaly between Pt. Serra and the shoal of Ruommoli. This anomaly has an amplitude of about $480 \mathrm{nT}$ and seems to be related to a positive contrast of magnetization. An anomaly with smaller amplitude and dimension occurs in correspondence with the area of the Formiche di Vivara submarine volcano. The values of the anomalies appear to be influenced by a long wavelength trend not detectable at our scale of study.
It should be noted that while the Formiche di Vivara submarine volcano was extensively studied (see the above cited authors), very little is known about the submarine source connected to the prominent anomaly measured between Pt. Serra and Ruommoli. A recent detailed survey of the bathymetry of the Phlegrean FieldsIschia offshore (De Alteris et al., 2006) showed that the pattern of the sea floor between Pt. Serra and Ruommoli outlines two small ridges. These ridges seem to roughly indicate the rim of a volcanic edifice (a tuff ring, see fig. 2), very likely older than the Vivara volcano. As we can see in fig. 4 the correspondence between the bathymetric rim and the magnetic anomaly is fairly distinct. Moreover, the amplitude of the anomaly let us suppose the existence of deposits with magnetization values higher than those normally characterizing tuffs. The geometry and magnetization of this structure is analyzed in the next section.

As regards the monogenic edifice La Catena, a hyaloclastite volcano of latitic composition (Di Girolamo and Rolandi, 1975), it is not associated with any meaningful isolated magnetic anomaly (fig. 4). This evidence suggests an absence of significant magnetization contrast between this volcano and its surroundings. However it should be noted that the area around La Catena is characterized by a NW-SE trending anomaly which could be related to smaller volcanogenic sources distributed along the faults characterizing the area between La Catena and the Ischia Island.

\subsection{Data Analysis and Interpretation}

In order to understand the nature of the magnetic source located between Pt. Serra and Ruommoli we performed a qualitative and quantitative analysis of the aeromagnetic data. The horizontal position of the causative source was determined by compiling a 3D analytic signal map (fig. 5a). This map clearly shows two separate bell shapes, a smaller one over the structure of Formiche di Vivara and a bigger one over the source located between Pt. Serra and Ruommoli. We named this structure as the Pt. Serra submarine volcano. 


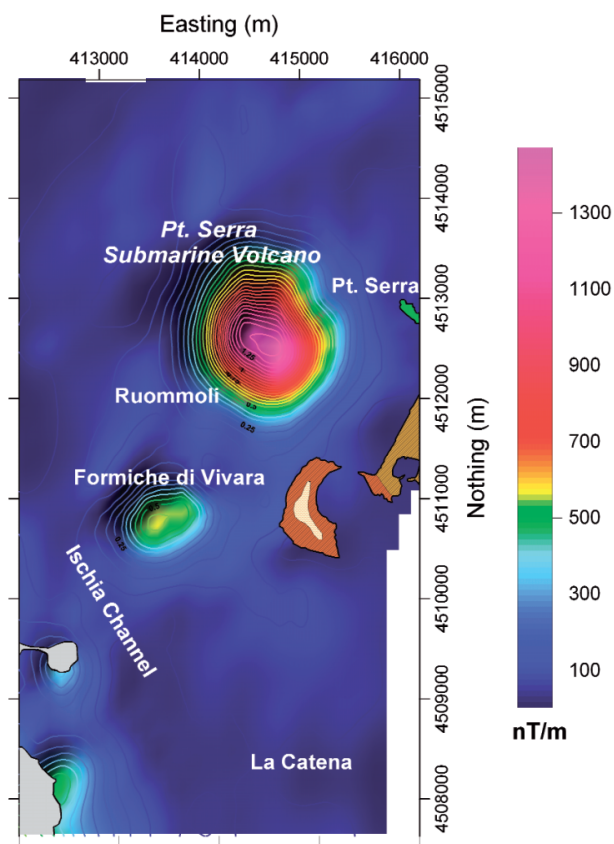

A)

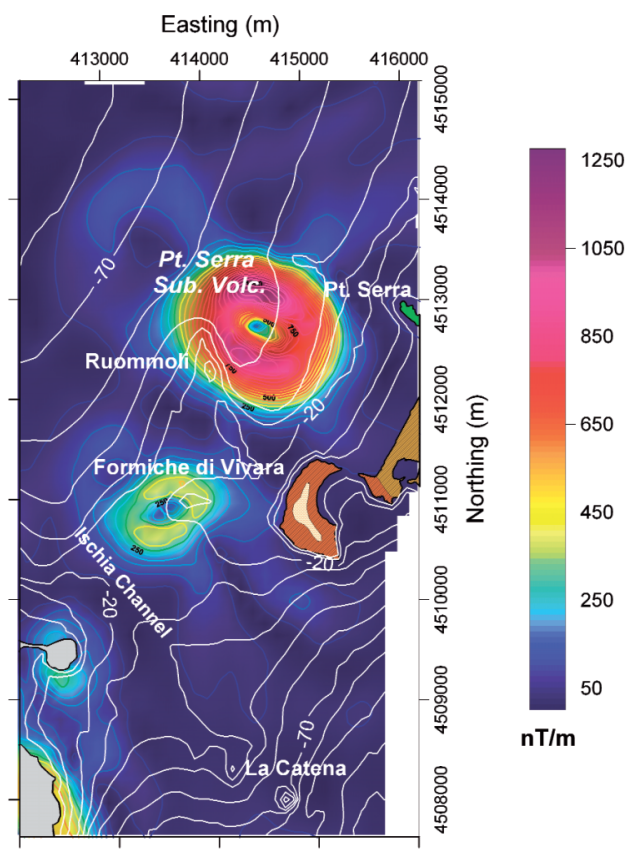

B)

Fig. 5a,b. A) 3D analytic signal map of the magnetic data set measured in the Western Procida offshore; B) 3D horizontal gradient map of the pole-reduced data set measured in the Western Procida offshore. White contours show the bathymetry of the area from De Alteris et al. (2006).

The lateral boundaries of both the above cited anomaly sources were clearly defined by analyzing the maximum horizontal gradient of the reduced to the pole data (fig. 5b). As we can see, the limits of the Pt. Serra submarine volcano indicated by the maxima of the horizontal gradient function correspond fairly well with the bathymetric pattern. Note that, as the horizontal gradient method assumes that the boundaries can be approximated as single, near-vertical, sharp boundaries, when the boundaries are not represented by a vertical contact or when several boundaries are close together, the location of the gradient maximum can be offset from the actual boundary.

In order to have an estimation of the geometric and magnetization characteristics of the Formiche di Vivara and Pt. Serra submarine volcano, we carried out a three-dimensional inversion of the magnetic field and computed Singular Value Decomposition (SVD) solu- tions. We used a nonparametric discretization of the inverse problem and assumed a source volume of specified depth and horizontal extent, in which the solution is piecewise constant within a three-dimensional grid of prisms (see, e.g., Fedi et al., 2005; 2007). In the adopted inversion approach the a priori information is incorporated in the regularization matrix in the form of high-order derivatives in the $\mathrm{x}, \mathrm{y}$ and $\mathrm{z}$ directions. Provided that enough SVD components are available for the solution - i.e., the problem is not strongly underdetermined and the data noise level is not too high - and a suitable regularization matrix is used, depth resolution can be obtained without resorting to any subjective choice of depth weighting.

The discretization used for the inversion is composed of $13 \times 13 \times 13$ prisms in the $\mathrm{x}, \mathrm{y}$, and $\mathrm{z}$ directions respectively, i.e., the solution consists of $N=2197$ prisms. The dimension of the prisms is $403 \mathrm{~m}$ in the $\mathrm{x}$ and $\mathrm{y}$ direction and $110 \mathrm{~m}$ in 

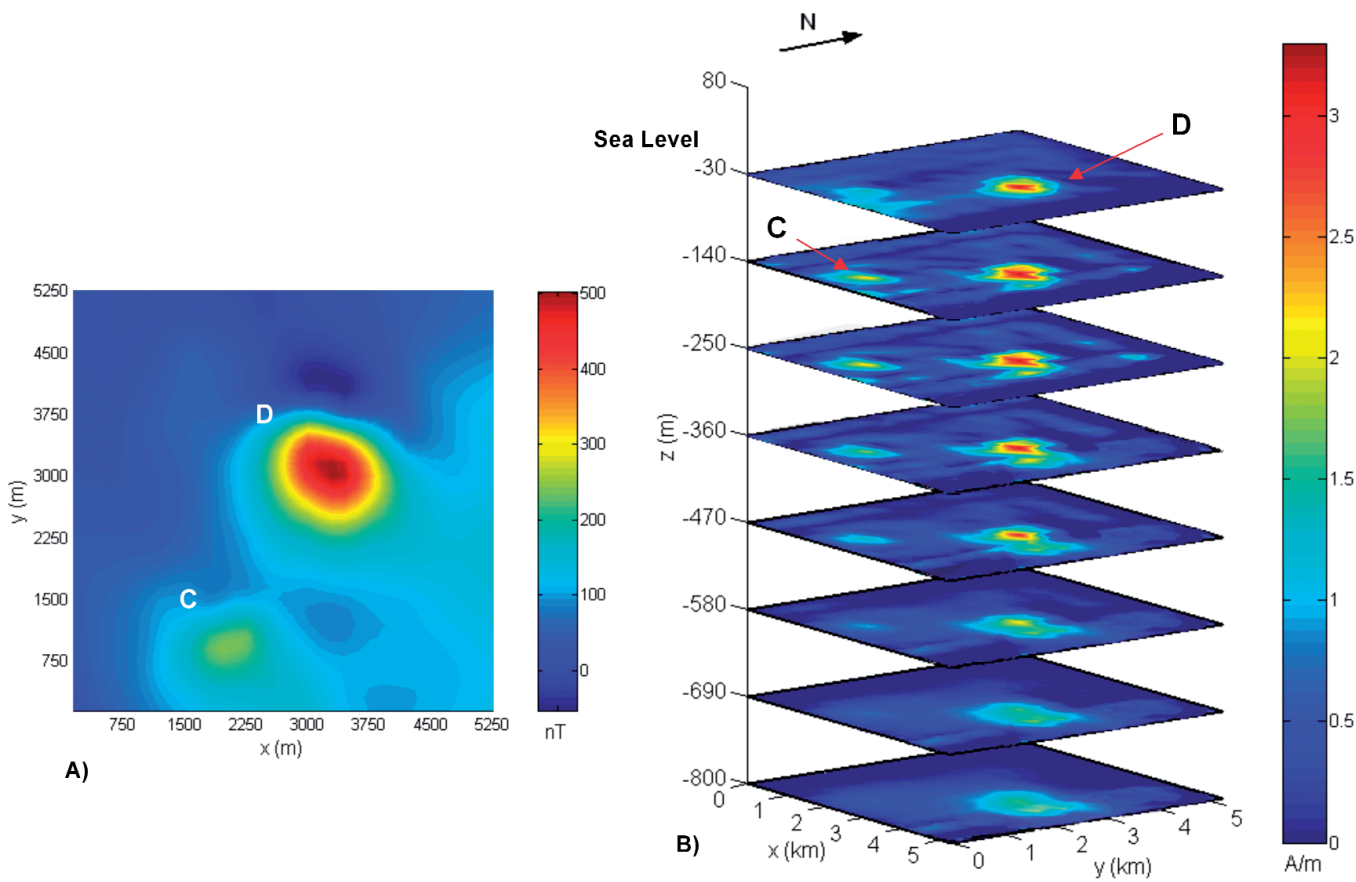

Fig. 6a,b. SVD (Singular Value Decomposition) inversion of the magnetic data. A) Data set used for the inversion; B) Three-dimensional magnetization model.

the $\mathrm{z}$ direction. Moreover, we used $P=1225$ data points arranged in a $35 \times 35$ grid, covering an area of $5.25 \times 5.25 \mathrm{~km}^{2}$. The data points are located $300 \mathrm{~m}$ above the sea level. Figure $6 \mathrm{a}$ shows the data we inverted, while in fig. $6 \mathrm{~b}$ we see the reconstruction obtained with 450 SVD components.

The solution shows the presence of two dyke-like bodies, a larger one relative to the anomaly measured over the Pt. Serra submarine volcano (D in fig. $6 \mathrm{~b}$ ) and a smaller one corresponding to the Formiche di Vivara anomaly ( $\mathrm{C}$ in fig. $6 \mathrm{~b}$ ). Both sources start from the sea floor, about 30 meters below sea level. But while the depth-to-the-bottom of the most magnetized part of the Formiche di Vivara source is less than $500 \mathrm{~m}$ b.s.1., the bottom of the Pt. Serra submarine volcano is much deeper. The inversion results obtained beneath about $1000 \mathrm{~m}$ b.s.l. cannot be trusted because of the loss of resolution with depth of the inversion.
An important feature shown by the inversion results is the maximum magnetization of the sources that is about $2 \mathrm{~A} / \mathrm{m}$ for the Formiche di Vivara body and $3.3 \mathrm{~A} / \mathrm{m}$ for the Pt. Serra submarine volcano. This suggests the presence of compact igneous material. The different value of magnetization of the two bodies could be explained by a different degree of alteration of the igneous material and/or a different thickness of the clastic deposits in the uppermost part of the bodies.

The above results were confirmed by $2 \mathrm{D}$ modeling of the data along a profile (see fig. 7a). The modeling was carried out by using GMSYS (Grav/Mag Modeling Software, www.nga.com), assuming a model compatible with that obtained from the inversion. As we can see in fig. $7 \mathrm{~b}$, a good fit between measured and computed data was achieved supposing the presence of two dikelike igneous bodies with magnetization values of 2.4 to $3.6 \mathrm{~A} / \mathrm{m}$ for Formiche di Vivara and the Pt. 


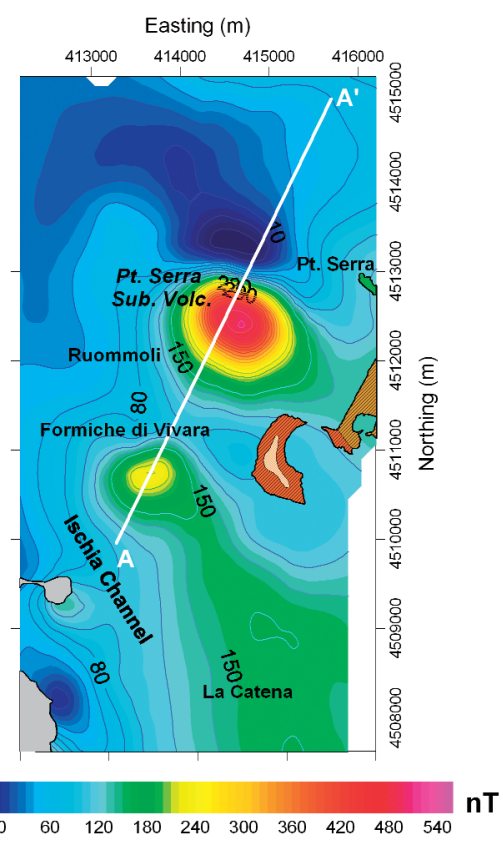

A)

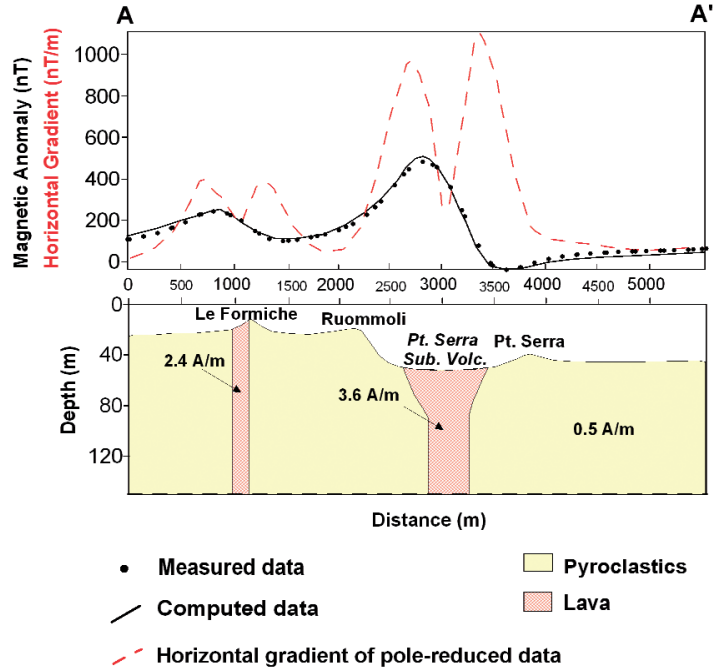

B)

Fig. 7a,b. Magnetic modeling along profile AA' of the anomalies measured over Formiche di Vivara and Pt. Serra submarine volcano. A) Location of the profile; B) 2D modeling. Here we show the shallowest 150 meters of the interpretative model.

Serra submarine volcano, respectively. The widths of these structures are about $200 \mathrm{~m}$ for the Formiche di Vivara source and 600-800 $\mathrm{m}$ for the Pt. Serra submarine volcano. The results of the modeling also show that the bathymetric rims of the Pt. Serra submarine volcano are characterized by low magnetization values. This may indicate the presence of pyroclastic material, such as tuff, in the outer rims of the volcano.

\section{Conclusions}

We performed a study of the Western Procida offshore analyzing and interpreting a detailed aeromagnetic data set recently measured in Ischia region (figs. 3a-3b). The area investigated is the submarine zone between the islands of Ischia and Procida, along the Phlegrean Fields-Ischia ridge (fig. 1). Here geological and volcanological studies (Di Girolamo and Rolandi, 1975; Ferranti et al., 1994; De Alteris et al., 1997; 2006) showed different monogenic submarine volcanoes aligned along a NE-SW system of faults.

The new high resolution aeromagnetic data (fig. 4) yielded new evidence on the area, highlighting the signature of a volcanic body placed between Pt. Serra and the shoal of Ruommoli that had not been clearly described and characterized before and that we named Pt. Serra submarine volcano. The position of this volcano was highlighted by the analytic signal map (fig. $5 a)$, while the horizontal gradient map located the rims of the structure and showed that these rims roughly follow the bathymetric pattern (fig. 5b).

The thickness and magnetization values of this volcano were obtained by a three-dimensional inversion of the magnetic data. The solu- 
tion showed a dyke-like igneous body extending to a depth of several hundred meters b.s.l., with a maximum magnetization of about 3.3 $\mathrm{A} / \mathrm{m}$ (fig. 6). A $2 \mathrm{D}$ modeling of the data (fig. 7) confirmed the outcome of the inversion.

The surveyed area also covered the Formiche di Vivara and La Catena volcanoes (figs. 3b-4). The analysis and interpretation of the data collected over the Formiche di Vivara volcano showed a dyke-like igneous body smaller than the Pt. Serra submarine volcano (figs. 6-7). The non-existence of prominent isolated magnetic anomalies over the monogenic hyaloclastite volcano of La Catena allowed us to argue the absence of significant magnetization contrast between this volcano and its surroundings.

\section{Acknowledgements}

The authors acknowledge the support of an INGV grant «Project V3_3 - Ischia» to one of the authors (AR). The authors are grateful to two anonymous reviewers for their constructive comments that were a great help in improving our paper and to B. McGann for language revision. The research was carried out in the framework of the National Research Project (PRIN) MIUR 2007LE8ZC5_003 (Sc. Resp. AR).

\section{REFERENCES}

Aiello, G., A. Angelino, B. D’Argenio, E. Marsella, N. Pelosi, S. Ruggieri and A. Siniscalchi (2005): Buried volcanic structures in the Gulf of Naples (Southern Tyrrhenian Sea, Italy) resulting from high resolution magnetic survey and seismic profiling, Annals of Geophysics, 48 (6), 883-897.

Bruno, P.P.G., G. De Alteris and G. Florio ( 2002): The western undersea section of the Ischia volcanic complex (Italy, Tyrrhenian sea) inferred by marine geophysical data, Geophysical Research Letters, 29 (9), 57 (1-4).

De Alteris, G., C. Donadio and L. Ferranti (1997): Morfologie e strutture di apparati vulcanici sommersi nel Canale d'Ischia (Mar Tirreno), Memorie Descrittive Carta Geologica d'Italia, 52, 85-96.

De Alteris, G., P.P.G. Bruno, E. Di Fiore, G. Florio, S. PASSARO and R. Tonielli (2002): Magnetic marine geophysical data (multibeam bathymetry, magnetics and seismics) in active volcanic area: the case of Ischia volcano and its offshore (Italy, Tyrrhenian Sea), Boll. Geof. Teor. Appl., 42, 45-47.
De Alteris, G. and F. Toscano (2003): Introduzione alla geologia dei mari circostanti le isole flegree di Ischia, Procida e Vivara, in: AA.Vv., Ambiente marino costiero e territorio delle isole flegree (Ischia, Procida e Vivara) e Golfo di Napoli. Risultati di uno studio multidisciplinare, Monografia Accademia di scienze Matematiche, Fisiche e Naturali, (Liguori Ed., Naples), pp. 77.

De Alteris, G., R. Tondelli, S. Passaro and M. De LauRO (2006): Isole Flegree (Ischia e Procida), (Liguori Ed., Naples), pp. 73.

De Santis, A., L.R. Gaya-Piqué, A. Dominici, A. Meloni, J.M. TORTA and R. TOZZI, (2003): Italian Geomagnetic Reference Field (ITGRF): update for 2000 and secular variation model up to 2005 by autoregressive forecasting, Annals of Geophysics, 46, n. 3, 491-500.

Di Girolamo, P. and D. Stanzione (1973): Lineamenti geologici e petrologici dell' isola di Procida, Rend. Soc. It. Min. Petr., 29, 82-125.

Di Girolamo, P. and G. Rolandi (1975): Vulcanismo sottomarino latitebasaltico-latitico (serie potassica) nel Canale d'Ischia (Campania), Rend. Acc. Sci. Fis. Mat., (Accademia Nazionale Scienze Lettere Arti in Napoli), S. 4, 42, 561-596.

Di Girolamo, P., Ghiara, M.R., Lirer, L., Munno, R., Rolandi, G. and D. Stanzione (1984): Vulcanologia e petrologia dei Campi Flegrei, Boll. Soc. Geol. It., 103, 349-413.

Fedi, M., P.C. Hansen and V. Paoletti (2005): Analysis of Depth Resolution in Potential Field Inversion: a Tutorial, Geophysics, 70, A1-A11.

Fedi, M., P.C. HANSEN and V. PAOLETti (2007): Ambiguity and Depth Resolution in Potential Field Inversion, Communications to SIMAI Congress (Electronic Journal), 2, doi: 10.1685/CSC06155

Ferranti, L., S. Bravi and G. De Alteris (1994): La secca delle Formiche di Vivara (Canale d'Ischia, Campania), osservazioni geomorfologiche-strutturali e faunistiche, Rend. Acc. Sci. Fis. Mat., (Accademia Nazionale Scienze Lettere Arti in Napoli, S. IV), 61, 50-65.

Imbò, G., V. Bonasia and P. Gasparini (1964): Rilievo gravimetrico dell'Isola di Procida, Ann. Oss. Vesuv., 6.

Paoletti, V., M. Fedi, G. Florio, R. Supper and A. RapolLA (2004): The new integrated aeromagnetic map of the Phlegrean Fields volcano and surrounding areas, Annals of Geophysics, 47, 1569-1580.

Paoletti, V., R. SupPer, M. Chiappini, M. Fedi, G. Florio and A. Rapolla (2005a): Aeromagnetic survey of the Somma-Vesuvius volcanic area, Annals of Geophysics, 48, 1596-1580.

Paoletti, V., M. Secomandi, M. Fedi, G. Florio and A. RAPOLLA (2005b): The integration of magnetic data in the Neapolitan volcanic district, Geosphere, 1, 85-96.

Paoletti, V., R. Di Maio, F. Cella, G. Florio, K. Mocka, N. Roberti, M. Secomandi, R. Supper, M. Fedi and A. RAPOLLA (2009): The Ischia Volcanic Island (Southern Italy): Inferences from Potential Field Data Interpretation, Journal of Volcanology and Geothermal Research, 179, 69-86.

Secomandi, M., V. Paoletti, G. Aiello, M. Fedi, E. Marsella, S. Ruggieri, B. D'Argenio and A. RaPOLLA (2003): Analysis of the magnetic anomaly field of the volcanic district of the Bay of Naples, Italy, Marine 
Geophysical Researches, 24, 207-221.

Siniscalchi, A., A. Angelino, S. Ruggieri, G. Aiello, E. MARSElla and M. SACCHI (2002): High resolution magnetic anomaly map of the Bay of Naples (Southern Tyrrhenian Sea, Italy), Boll. Geof. Teor. Appl., 42, 99104.
VEZZoLI, L. (Ed.) (1988): Island of Ischia, Quaderni de «La Ricerca Scientifica», (Cnr, Progetto Finalizzato Geodinamica), 10, pp. 126.

(received November 29, 2007; accepted April 29, 2008) 